UDC 658:332

JEL Classification: 129, D79, D81

http://doi.org/10.21272/mmi.2019.1-21

\author{
Olga Farhshatova
}

Ph.D., Institute for International Cooperation Development, Poland

Sergey Zaharov,

Ph.D., Metinvest PromServis, Ukraine

Mykhaylo Vereskun,

D.Sc., Priazovsky State Technical University, Ukraine

Valeriia Kolosok,

D.Sc., Priazovsky State Technical University, Ukraine

\title{
FORMATION OF COMPETITIVE ADVANTAGES OF THE ENTERPRISE BASED ON ADAPTIVE MANAGEMENT
}

Abstract. In the paper based on research and generalization of many separate scientific studies, the content of the concepts of "competition» and "competitiveness of the enterprise» is formed. The actuality of the problems of competition and loss of competitiveness of enterprises in the conditions of deepening and spreading of consequences of economic crises, which suppress practically all branches of industry and economy of Ukraine, is revealed. The views on the interpretation of the concepts of adaptation and adaptive management by industrial enterprises are analysed and summarized, and the necessity for modern enterprises to apply different methods of adaptation in management processes is grounded. The concept of formation of competitive advantages of the enterprise on the principles of adaptive management is proposed, based on the complex dynamic approach, the interrelation of the principles of adaptability, flexibility, efficiency, interconnection, adequacy and controllability with the possibility of development of competitive advantages of the enterprise is investigated. The task of the concept corresponds to the application of adaptive integrated systems; system planning in the industry and adaptive regulation system; development of expected indicators of competitive advantages of the enterprise and deviations from them; modelling adaptive response to changes in the real economic system. This concept allows the process of managing the competitive advantages with the maximum efficiency due to the sensitive response both to external unpredictable changes in the industry and internal potential changes in the enterprise. An analysis of the current dynamic conditions of the functioning of industrial enterprises has been carried out, a number of external and internal problems have been identified, including unfavourable investment climate, the need to match the achievements of scientific and technological progress (with the widespread introduction of advanced technologies) and the lack of a management strategy in changing market conditions. It is proved that for industrial enterprises, the application of the principles of adaptive control as a competitive advantage is a decisive factor in achieving their sustainable competitiveness in the market of fuel energy, which is one of the strategic tasks of creating an effective system of management at enterprises that would provide them stable.

Keywords: adaptive management, competitive advantages, crises, industrial enterprises, management of competitive advantages.

Introduction. The conditions of a national market economy in which modern industrial enterprises operate in general are characterized by an increased degree of instability and rapid volatility, as well as the dynamics of slowing down of economic growth processes. Significant economic problems, such as excessive liberalization of market foreign economic relations; imperfection of current legislation and regulatory policy; high competition, etc., as well as changes in production, trade, science and technology, require increased attention from enterprise management to the dynamic conditions of operation and management decisions using flexible adaptive tools.

The necessity and importance of the application of the principles of adaptive management in shaping and assessing the competitive advantages of industrial enterprises (CAIE) in Ukraine are related to a

Cite as: Farhshatova, O., Zaharov, S., Vereskun, M., \& Kolosok, V. (2019). Formation of Competitive Advantages of the Enterprise Based on Adaptive Management. Marketing and Management of Innovations, 1, 244256. http://doi.org/10.21272/mmi.2019.1-21 

Adaptive Management

number of problems, such as unfavourable investment climate; inconsistency of Ukraine's energy legislation with EU legislation; the need to match the achievements of scientific and technological progress, with the widespread introduction of advanced technologies and the lack of a management strategy in a changing market environment. For the enterprises of the fuel and energy industry, the application of the principles of adaptive management (AM) today becomes a decisive factor in the growth of competitiveness in the energy market, which is one of the strategic objectives for the establishment of an effective management system at enterprises that would provide them with stable CAIE.

Literature Review. Problems of competition, competitive advantages, the choice of competitive strategies and other aspects of the competitiveness of industrial enterprises are disclosed in the works of the classics of world economic science - A. Smith, D. Ricardo, J. Mill, M. Porter, J. Schumpeter, A. Chandler, K. McConnell and S. Brue, F. Knight, F. Hayek, M. Meescon, M. Albert, F. Kotler, H. Mezer, B. Carlofa, G. Hemela, K. Prahlada, G. Azoyeva, K. Pajak, B. Kaminska, V. Lachno, L. Karpenko, A. Kwilinski, I. Balabanova, P. Fatkhutdinova and others. Investigating these questions, scientists have made a significant contribution to the study of competitiveness issues. At the same time, neither theoretical generalizations of foreign experience nor the practical experience of foreign managers can be fully transposed into Ukrainian soil, as modern Ukraine is characterized by unstable economic development, lack of experience in effective functioning and management of competitive advantages.

Underlying the modern idea of competition are the ideas of the European Enlightenment XVIII century. The first most unitary theoretical positions about the driving forces of behavioural competition. So, A. Smith compared competition with the «invisible hand» of the market, that is, a mechanism that automatically provides market equilibrium, efficiency, proportionality and dynamism of the market economy. D. Ricardo noted the influence of competition on the production of goods (Zlupko, 2005).

According to J. C. Mill's theory, competition is «the only regulator of prices, wages, rent; the law establishing the rules of this regulation» (Bartenev, 1997). In view of this, the emphasis of classical economists was on the study of perfect competition.

A. Marshall more fully justifies the mechanism of automatic equilibrium in the market by means of competition and the laws of marginal utility and marginal productivity (Marshall, 1983).

M. Porter considered competition in the world economy as an economic lever of increasing production and stimulating the quality of products, adapting it to the needs of consumers, an objective condition for the functioning and development of an industrial enterprise on the basis of the international division of labour (Porter, 1993, 1997).

From the view $F$. Hayek on the market only due to the concealed competition becomes obvious. It is implied that due to competition from the same lines of behaviour, firms can be chosen more effectively if there is not enough information (Hayek, 1999). R. Fatkhuddinov proposed to consider competition as «the process of managing $\mathrm{CA}$ to achieve victory or achieve other goals in the fight against competitors to meet objective or subjective needs in the framework of legislation or in natural conditions. Competition is the driving force behind the development of subjects and objects of governance, society as a whole» (Head and Alford, 2008; Fomin and Fradkov, 1981). M. Lepa considers that competition is «rivalry between producers of goods and services for the most economically advantageous terms of production and sales» (Zyblitskaya, 2012).

The above definitions and interpretations of the concept of «competition» reaffirm the idea that this economic category is universal and applicable to the object of study of any scale. Moreover, it has long crossed the boundaries of economic science, and now it is used by representatives of all social sciences to assess the behaviour or the course of processes in a particular environment. The authors of this paper adopt an approach that will help to consider the behaviour of the investigated economic object in an unstable economic environment of Ukraine. 

Adaptive Management

Consequently, competition will be considered as a dynamic and coordinated process of the struggle of rivals for the most favourable conditions of existence in an unstable external environment in order to achieve their own goals. The concept of «competition» is inextricably linked with the notion of "competitiveness», the complexity and universality of which also require a more accurate assessment and definition. Today, the concept of competitiveness, as well as competition and competitive advantage, is widespread in all areas of the functioning of any state. They are considered in relation to the economy of the state, enterprises, resources, goods. Competitiveness of the state or enterprises in the scientific literature is often considered as a generalized property, which is characterized by a set of indicators responsible for the formation of competitive advantages.

This paper examines competitiveness in relation to the activities of enterprises and is understood as the ability to effectively adapt the strategy and tactics of the company to the conditions of market competition, which allows producing products that, by their parameters, are of greater interest to consumers than the products of competitors.

But to be competitive means not only the ability to withstand competitors but also to win them in a competitive struggle. In addition, in the face of aggravation of such a struggle, the strengths and weaknesses of enterprises are detected, and those who have powerful CAIEs will win.

Directly to the problems of the formation of competitive advantages and their best use, the representatives of various areas of economic science. $R$. Fatkhuddinov conducted a critical analysis of the theory of M. Porter, as a result, he proposed to consider the competitive advantage of an object with the help of the term «value». "Value, from the point of the author view is system possesses (includes); aspires to keep or to have in the future. The competitive advantage of the system is any exclusive value that is inherent in the system and gives it advantages over its competitors» (Zyblitskaya, 2012). A significant contribution to the understanding of the concept of KP, made by R. Fatkhutdinov, opens up opportunities for the study of an unlimited number of factors of competitive advantage. But this definition does not reveal the reasons for the formation of such a value (Fathutdinov, 2000).

T. Peter and B. Waterman formulated general principles that provide competitive advantages to producers (Zyblitskaya, 2012): the targeting of all and every employee to act, to continue the proceedings; proximity of the enterprise to the client; creation of an autonomy and creative atmosphere at the enterprise; productivity growth through the use of people's abilities and their willingness to work; ability to firmly stand on its own; ease of organization, minimum levels of management and service personnel; ability to be both soft and firm; to keep the most important issues under tight control and to pass on less important issues to subordinates (Zyblitskaya, 2012).

A detailed dialectical analysis of the definition of «competitive advantages» made it possible to conclude that approaches to the development of the research problem in the world scientific literature are quite diverse, and there is no single understanding and general understanding of the concept of "competitive advantages».

Consequently, in our opinion, it is appropriate to understand the competitive advantage of a complex of unique characteristics of various spheres of the enterprise (economic, technical, organizational, etc.) that determine the situation of the enterprise in the sectoral market, form a difference from competitors, which manifests itself in the more effective conduct of economic activity of the enterprise and ensures the stable functioning, survival and development of the enterprise in the modern economy.

Considering the competitive advantages of the enterprise, the factors on which the difference between the enterprise and its competitors depends, as well as the position of the firm in the sectoral market, there is a need to influence these factors (to manage them) in order to achieve more effective competition for economic activity and ensure a stable functioning, survival and development enterprises of the modern economy. 

Adaptive Management

Consequently, concepts substantially and deeply characterize the definition of concepts of adaptation and adaptive management. In general, it is determined that the most significant disadvantage of the considered definitions is the incomplete consideration of the available objective factors that determine the possibility of a variety of adaptive management. Also remains unexplored the issue of the peculiarities of this process for industrial enterprises. Its solution will more reveal the essence of the process of forming the competitive advantages of industrial enterprises on the basis of adaptive management.

Therefore, the essence of the definition of «the formation of competitive advantages of the enterprise based on adaptive management» is relevant to consider as the necessary purposeful process of rapid and optimal adaptation of the structure and parameters of the competitive advantages of the industrial enterprise to sudden and unpredictable changes in the external environment, taking into account their possible alternatives and consequences and ability to interact with the modified environment and the individuality of its activities.

Economic science has accumulated a huge supply of theoretical and methodological approaches to solving the issues of the formation of a CAIE, there is an intensification of modern research in this direction, but at the same time, most of them have the result of theoretical recommendations, while there is an urgent need to develop practical methods for solving the problem. In addition, in these works, the study of theoretical and practical aspects of the formation of CAIE based on AM taking into account sectoral peculiarities of its development, in general, is not paid attention.

Insufficient research and general unresolved problems in the implementation of the process of formation of CAIE on the principles of adaptive management, the need to strengthen the scientific component in the development of a comprehensive assessment of the effectiveness of the application of the principles of AM in industrial enterprises led to the choice of the topic, its relevance and identified the purpose and objectives of the study.

Methodology and research methods. The transformational processes taking place in the Ukrainian economy are aimed at the formation of a highly effective socially oriented market economy. But the current situation is characterized by a crisis in Ukrainian enterprises that manifested themselves well before the aftermath of the global crisis and, first of all, increased competition and lack of experience in managing the competitive advantages in a changing environment, as well as the imperfection of the regulatory framework for regulating the behavior of a market entity. This is accompanied by an outdated technical and technological base of most domestic industrial enterprises, high specific consumption of resources and the use of old approaches to the management of industrial and economic activities of enterprises. Management is called the cyclical process of achieving goals in a managed system, which includes four stages: goal setting; planning; monitoring and evaluation. But for successful influence on the system, it is necessary to determine the understanding of scientific approaches to management.

In cases where the enterprise development plan deliberately does not take into account some possible states of the environment, at their occurrence, a situation may arise when the goals are achieved or will not be achieved in full, or their achievement will only be dreamed of. That is why it is necessary to use adaptive control methods that are intended to anticipate the effect of destabilizing factors and to ensure an adequate reaction of the enterprise to them.

Figure 1 shows a conceptual model, which developed by authors for the creation of CAIE based on adaptive control. In the paper as the main concept it is proposed to consider a complex dynamic approach to the formation of CAIE on adaptive management of the competitive advantages of an industrial enterprise based on adaptively-integrated tasks of an integrated approach that corresponds to the following directions:

- application of adapted integrated systems that contain flexible means of adjusting the characteristics of competitive advantages on the features of the enterprise sector; 
O. Farhshatova, S. Zaharov, M. Vereskun, V. Kolosok. Formation of Competitive Advantages of the Enterprise Based on Adaptive Management

- the application of two interrelated systems: an adaptive sector planning system and an adaptive regulatory system;

- application of the system of quantitative and qualitative researches, within the framework of which the expected indicators of competitive advantages of the enterprise and admissible deviations from them are developed;

modelling adaptive responses to changes in the real economic system with the use of probabilistic methods in making decisions in a changing environment.

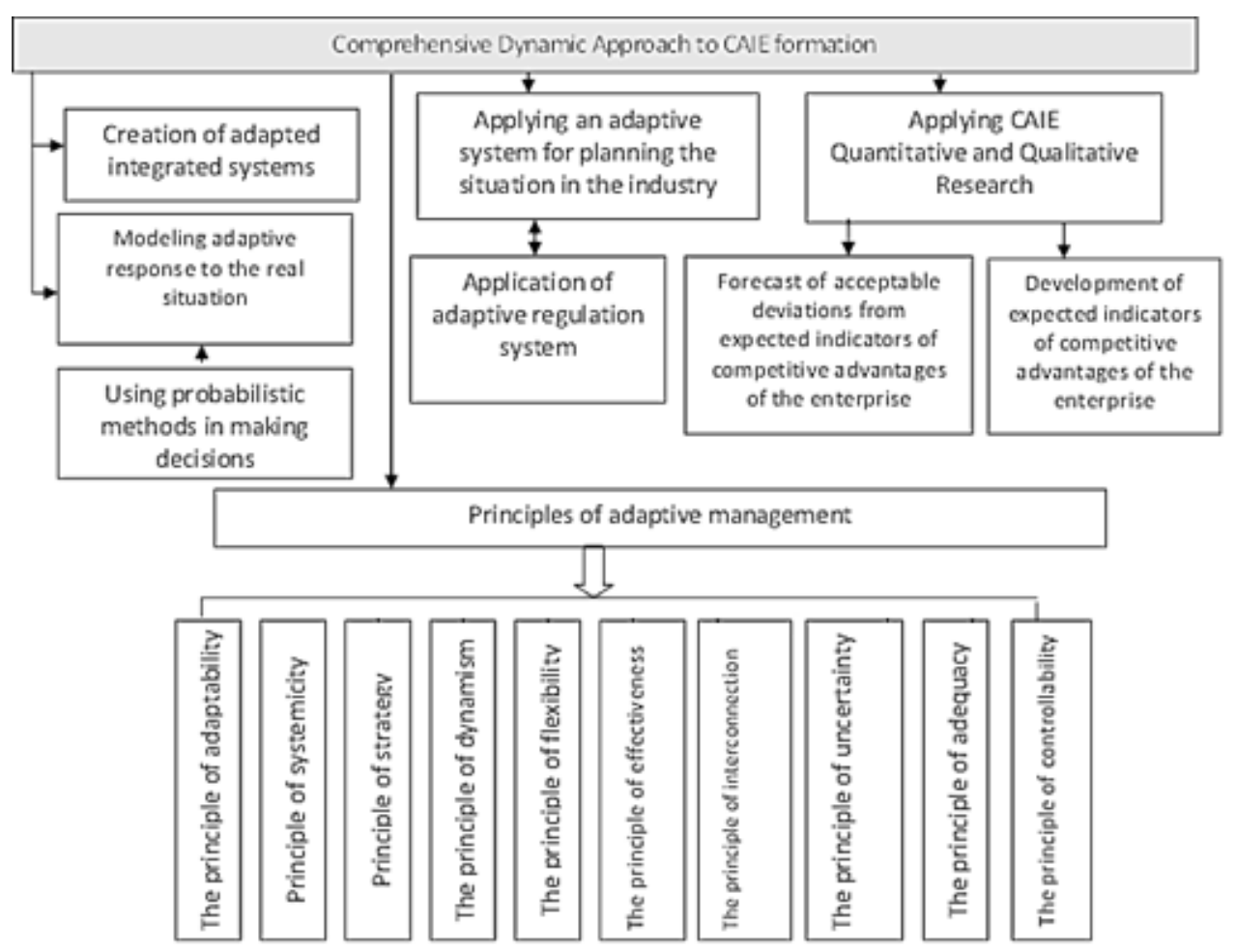

Figure 1. The comprehensive dynamic approach to the formation of CAIE based on AM Sources: developed by the authors.

The problem of adaptive control is a widely used method of continuous models. Instead of solving the problems of analysis or synthesis for the original system, you can try to solve a similar problem for its deterministic or stochastic continuous model, relying on the fact that a new task will be easier than the previous one. This substitution is the essence of the method of continuous models (Derevitsky and Fradkov, 1980).

The method of indirect decentralized adaptive control is used to estimate a small number of parameters (in particular, load parameters, ie mass and inertial characteristics). Estimated parameters are used further in setting the coefficients of the gain decentralized controller (Vukobrativych et al., 1989)

The widespread distribution was obtained by the network method proposed by M. Yu. Kozlov. It is associated with the application of a particular type of semantic network, which is represented as a graph. The vertices of the graph correspond to some objects, and to arcs - the relationship between these objects. Objects can be concepts or properties. The relations between objects in a semantic network can 

Adaptive Management

be described on the basis of the theoretical plural, logical formalism (Kozlov, 1980). A network model is particularly important for considering complex environments and the organization of finding solutions when using other methods is too complicated. The effectiveness of the network method, the author determines by two main factors: the accuracy of the representation of the network of objective connections between the elements of the problem environment and the direction of the concept received (the convenience of its use to form an adequate strategy). The network method involves the possibility of changing the structure of the network and (or) the links between its objects.

The starting point for calculations was a system of indicators that show the financial status and production potential of enterprises, which are reflected in the accounting and statistical reports of enterprises.

Results. The principles of adaptability, strategy, dynamism, flexibility, efficiency, interconnectivity, uncertainty, adequacy and manageability are based on the integrated dynamic approach to CAIE formation on the principles of adaptive management.

Consequently, the formation of the CAIE based on adaptive management is a challenge for enterprises operating in difficult times of crisis, which is important and requires quick and dynamic solutions.

Based on the concept of forming the competitive advantages of an industrial enterprise which based on $\mathrm{AM}$, an integrated dynamic approach is considered, the tasks of which are the application of adapted integrated systems; sector planning systems and adaptive regulation system; development of expected indicators of competitive advantages of the enterprise and deviations from them; modeling adaptive response to the real economic system; using of probabilistic methods in making decisions in a changing environment.

One of the determining factors that cause of using adaptive models is the unsteadiness of the external environment. The impossibility of a formal description of disturbing influences in economic and social systems is due to the specific nature of the deviations in the respective processes, with the probabilistic nature of their manifestation. The need to take into account changes in the environment in conditions of uncertainty leads to the application of adaptive models. Adaptation of the formal model is carried out according to the current and predicted information on the input and output changes of the system.

In practice, the optimal combination of management methods in each particular situation is of great importance, since it is virtually impossible to achieve the desired results using only one method. The most commonly used in their totality (system), which is in constant dynamic equilibrium, and one method is supplemented, amplified by another or a group of methods.

In the context of the approach to the formation of competitive advantages of the enterprise, an important issue is the development of methods that take into account the peculiarities of modern economic conditions that can be determined, which based on theoretical analysis of existing and applied methods of adaptive management.

So, the classical theory of management offers algorithms that ensure the achievement of the goal concrete, precisely set object. If the description of the object there are omissions and uncertainties that make it an element of a class, then the traditional methods prove to be unsuitable. The easiest way out of this situation is to try to collect the missing information while managing the object and, as it receives, improve the management algorithm. Then from the moment, all information is received (or at the limit, if there is no such moment), the purpose of the management will be achieved. This idea lies at the heart of the identification method of adaptive control (Sragovich, 1981).

The essence of this method consists in the following: to carry out both the procedure of studying the object, its identification (by evaluating its values that characterize the functions and parameters) and management (apply the classical methods of management of the situation).

The identification method has such an outline postulate: for successful management, it is imperative to know as much about the object as possible. In the framework of the identification approach to adaptive 

Adaptive Management

management, a general adaptive control method is widely developed, which is widely used as an adaptation algorithm.

In modern conditions rather unstable market relations the most important factor that determines the effectiveness of the existence of the CAIE is the unpredictability factor. This unpredictability comes mainly from the external environment: from the stateside, from the markets of raw materials and capital; from the consumer market. As a result, the operation of the enterprise takes place in conditions of economic, sociopolitical, legal, informational, and other risks, more complete and advanced forecasting is more complicated.

By systematizing the main theoretical approaches to the definition of the essence of managing the competitive advantages based on adaptive approach, it was found that the principle of adaptability is determined by the ability of the system to control the competitive advantage of the enterprise to effectively perform the general management functions in the cycle of enterprise management and specific functions in accordance with changes in the internal and external environment of the enterprise.

The conceptual approach to the process of forming CAIE based on AM is proposed, which is based on adaptively-integrated, planned-regulatory, differential, modular, control-predictive and probabilisticadaptive approaches. A conceptual approach involves the use of adapted integrated systems; sector planning systems and adaptive regulation system; development of expected indicators of competitive advantages of the enterprise and deviations from them; the use of probabilistic methods in making decisions in a changing environment, enabling adaptive responses to unpredictable changes in the economic system.

The overall results from the application of the conceptual approach to the formation of CAIE based on AM and the introduction of adaptive management methods at PJSC DTEK «Donetskoblenergo» amounted to 135.97 thousand UAH, Donbassenergo, 473.22 thousand UAH.

Total expenses of PJSC DTEK «Donetskoblenergo» amounted to 127.63 thousand UAH. Including implementation costs amounted to 101.76 thousand UAH, service costs -25.87 thousand UAH. The total expenses of PJSC «Donbasenergo» amounted to 127.63 thousand UAH, incl. the cost of implementation amounted to 101.76 thousand UAH, service costs -25.87 thousand UAH.

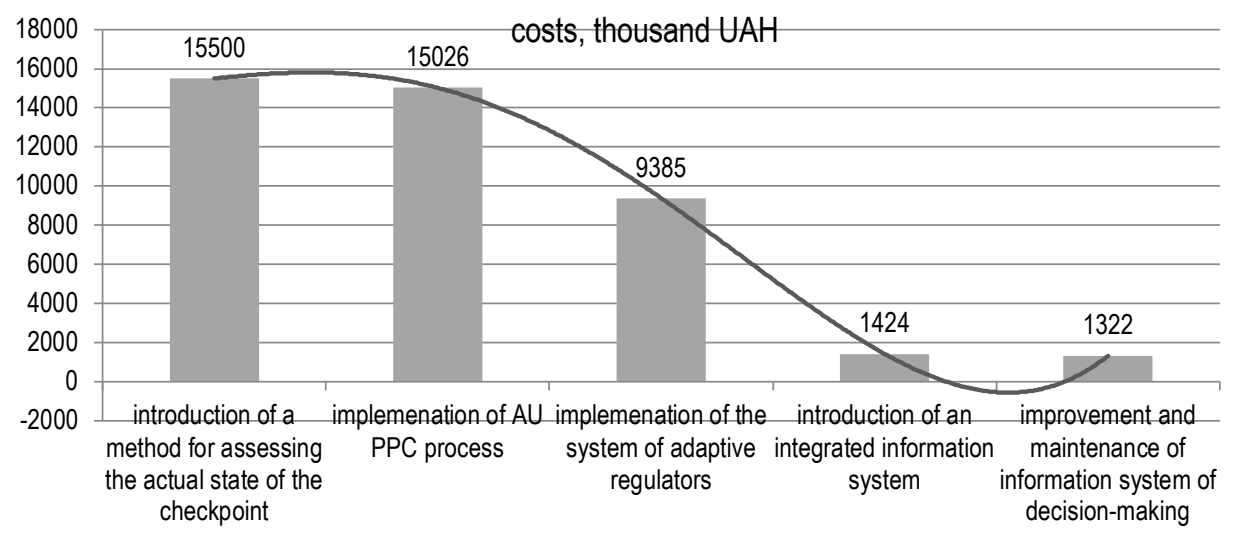

Figure 2. Sources (UAH, thousand), which determined the economic effect of implementing the results of developments at PJSC «Donbasenergo», Ukraine

Sources: developed by the authors. 
O. Farhshatova, S. Zaharov, M. Vereskun, V. Kolosok. Formation of Competitive Advantages of the Enterprise Based on Adaptive Management

Note that the cost of maintaining the process of forming CAIE based on AM is low because in this paper of expenditure were included only direct costs to support the performance of its hardware, other costs, including employees individual entrepreneur, were attributed to management costs.

This situation is associated with the replacement of the functions of individual workers in the process of planning the activities of the enterprise new, due to the introduction of the methods proposed in this work AM.

Consequently, the economic effect of applying the proposed methods of AM to PJSC «DTEK Donetskoblenergo» and PJSC «Donbasenergo» amounted to 135.97 thousand UAH and 473.22 thousand UAH. The effectiveness of the proposed system of adaptive control of CAIE under conditions of instability at PJSC «DTEK Donetskoblenergo» and PJSC «Donbasenergo» was 1.07 and 1.03, according to the calculation method, which is proposed in the work.

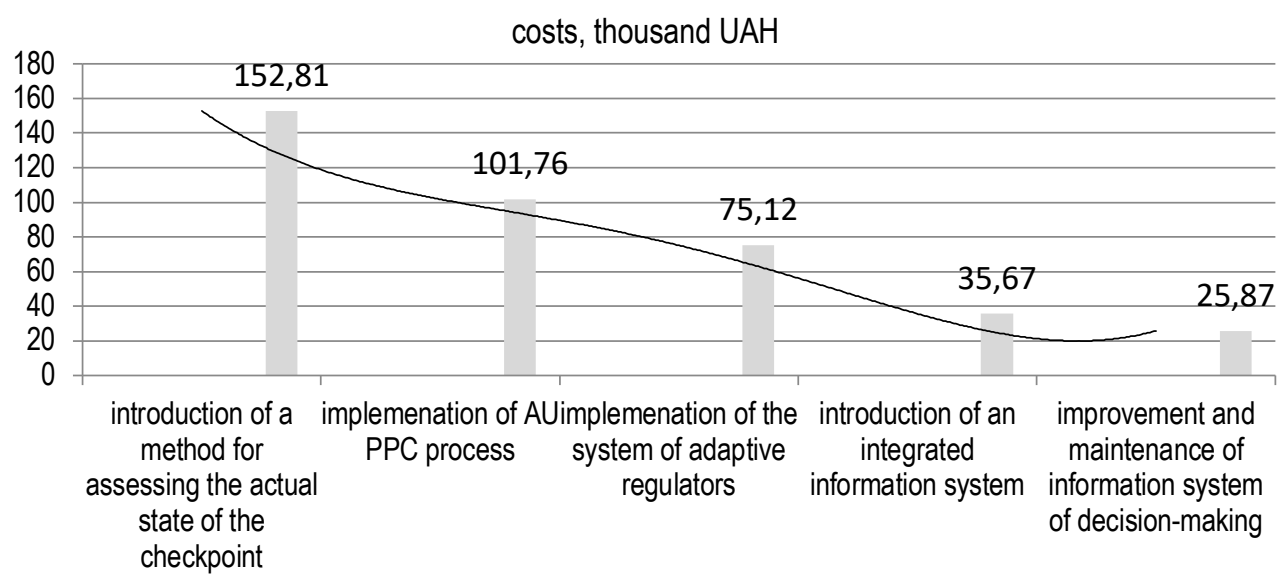

Figure 3. Sources (UAH, thousand), which determined the economic effect of implementation of development results at PJSC «DTEK Donetskoblenergo», Ukraine

Sources: developed by the authors.

According to the proposed structural scheme of the regulation of the actual state of the checkpoint, decisions are made to timely eliminate the deviations of indicators from the normative values with the least time losses for the enterprise is shown in Fig. 4.

Table 1. and Table 2. show the results of calculation of generalizing integral indicators of the real state of the competitive advantages of an industrial enterprise before and after the introduction of the proposed process of forming competitive advantages based on the principles of adaptive management

Table 1. Results of the calculation of the integral index of the real state of the checkpoint before and after the implementation of the proposed process of formation of the checkpoint based on AM (PJSC «Donbasenergo», Ukraine)

\begin{tabular}{|c|c|c|c|c|c|c|c|}
\hline \multicolumn{2}{|c|}{$\begin{array}{l}\text { Investigated } \\
\text { competitive advantages }\end{array}$} & \multicolumn{7}{|c|}{ PJSC «Donbasenergo» } \\
\cline { 3 - 9 } & Potential & Result & Specific & Resource & Sources & Cost \\
\hline \multicolumn{2}{|c|}{$\mathbf{1}$} & $\mathbf{2}$ & $\mathbf{3}$ & $\mathbf{4}$ & $\mathbf{5}$ & $\mathbf{6}$ & $\mathbf{7}$ \\
\hline \multirow{2}{*}{$\mathrm{A}$} & befor & 0,13 & 0,049 & 0,296 & 0,199 & 0,94 & 0,081 \\
\cline { 2 - 8 } & after & 0,14 & 0,1 & 0,3 & 0,21 & 0,94 & 0,12 \\
\hline
\end{tabular}


O. Farhshatova, S. Zaharov, M. Vereskun, V. Kolosok. Formation of Competitive Advantages of the Enterprise Based on Adaptive Management

\begin{tabular}{|c|c|c|c|c|c|c|c|}
\hline \multicolumn{10}{|c|}{ Continue Table 1 } \\
\hline \multirow{2}{*}{$\mathbf{1}$} & $\mathbf{2}$ & $\mathbf{3}$ & $\mathbf{4}$ & $\mathbf{5}$ & $\mathbf{6}$ & $\mathbf{7}$ \\
\hline \multirow{2}{*}{ B } & befor & 0,43 & 0,11 & 0,32 & 0,55 & 1,18 & 0,04 \\
\cline { 2 - 8 } & after & 0,45 & 0,12 & 0,41 & 0,50 & 1,03 & 0,9 \\
\hline \multirow{2}{*}{ D } & befor & 0,23 & 0,15 & 0,18 & 0,09 & 0,02 & 0,11 \\
\cline { 2 - 8 } & after & 0,31 & 0,22 & 0,19 & 0,1 & 0,5 & 0,11 \\
\cline { 2 - 8 } & befor & 0,4 & 0,3 & 0,46 & 0,05 & 0,14 & 0,14 \\
\hline \multirow{2}{*}{ E } & after & 0,4 & 0,37 & 0,5 & 0,1 & 0,7 & 0,145 \\
\cline { 2 - 8 } & befor & 0,08 & 0,33 & 0,43 & 0,35 & 0,9 & 0,05 \\
\hline \multirow{2}{*}{ F } & after & 0,145 & 0,5 & 0,43 & 0,39 & 0,9 & 0,1 \\
\cline { 2 - 8 } & befor & 0,15 & 0,17 & 0,12 & 0,16 & 0,42 & 0,03 \\
\hline \multirow{2}{*}{ G } & after & 0,2 & 0,19 & 0,2 & 0,23 & 0,64 & 0,12 \\
\cline { 2 - 8 } & befor & 0,38 & 0,43 & 0,41 & 0,19 & 0,81 & 0,2 \\
\hline \multirow{2}{*}{ H } & after & 0,45 & 0,5 & 0,42 & 0,45 & 0,9 & 0,23 \\
\cline { 2 - 8 } & befor & 0,47 & 0,27 & 0,16 & 0,34 & 0,73 & 0,24 \\
\hline & after & 0,47 & 0,3 & 0,173 & 0,41 & 0,77 & 0,24 \\
\hline
\end{tabular}

Note: $A$ - use of own capacities; $B$ - useful electricity output; $C$ - electricity tariffs; $D$ - installed electric power; $\mathrm{E}$ - science-intensive technologies; $\mathrm{F}$ - the intensity of production; $\mathrm{G}$ - commodity products; $\mathrm{H}$ investment attractiveness.

Sources: developed by the authors

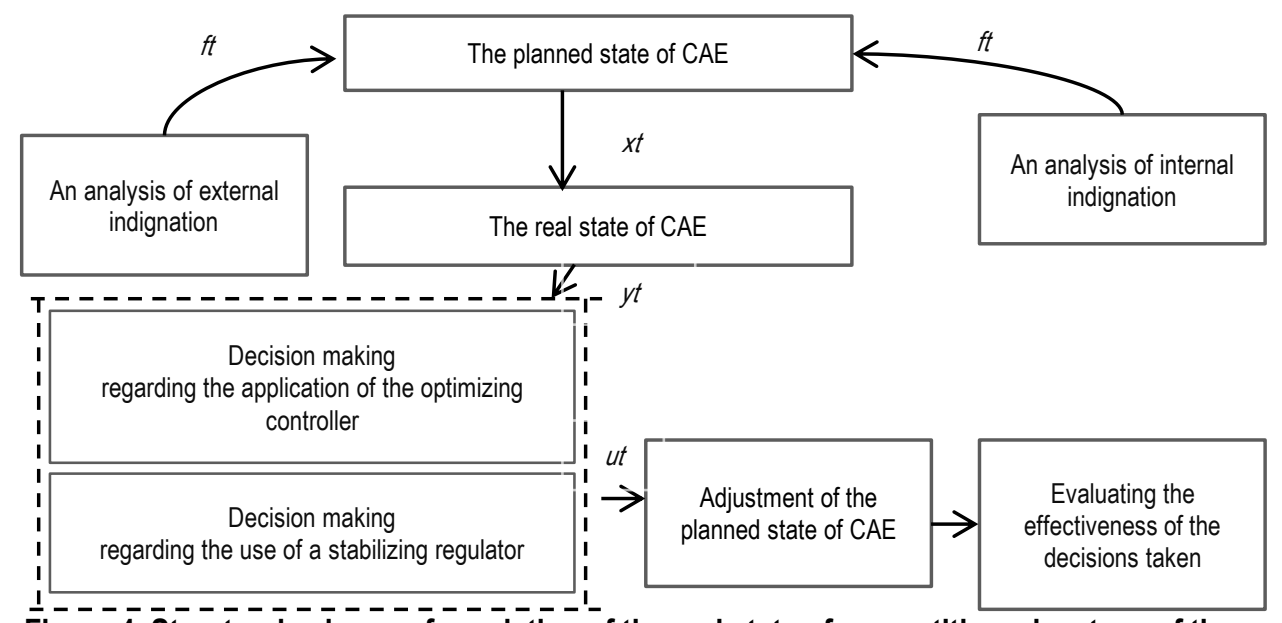

Figure 4. Structural scheme of regulation of the real state of competitive advantage of the enterprise

Note: $\mathrm{u}_{t}$ - independent variables - information about the control parameters (regulators) of the state of competitive advantages of the enterprise (CAE) the real state of CAE; $x_{t}$ - input variables - a set of scheduled variables, that characterize planned state indicators $\mathrm{CAE} ; f_{t}$ - indignation - information about the obstacles that derive from the current state of equilibrium $C A E$, the impact of which should be minimized; $t$-current setting value.

Sources: developed by the authors. 
O. Farhshatova, S. Zaharov, M. Vereskun, V. Kolosok. Formation of Competitive Advantages of the Enterprise Based on Adaptive Management

Table 2. Results of the calculation of the integral index of the real state of the checkpoint before and after the implementation of the proposed process of formation of the checkpoint based on AM (PJSC «DTEK Donetskoblenergo», Ukraine)

\begin{tabular}{|c|c|c|c|c|c|c|c|}
\hline \multirow{2}{*}{\multicolumn{2}{|c|}{$\begin{array}{l}\text { Investigated } \\
\text { competitive } \\
\text { advantages }\end{array}$}} & \multicolumn{6}{|c|}{ PJSC «DTEK Donetskoblenergo» } \\
\hline & & \multirow{2}{*}{$\begin{array}{c}\text { Potential } \\
2 \\
\end{array}$} & \multirow{2}{*}{$\begin{array}{c}\text { Result } \\
3 \\
\end{array}$} & \multirow{3}{*}{$\begin{array}{c}\text { Specific } \\
\mathbf{4} \\
0,331\end{array}$} & \multirow{3}{*}{$\begin{array}{c}\text { Resource } \\
\mathbf{5} \\
0,412 \\
\end{array}$} & \multirow{3}{*}{$\begin{array}{c}\text { Sources } \\
\mathbf{6} \\
0,228\end{array}$} & \multirow{3}{*}{$\begin{array}{c}\text { Cost } \\
\frac{7}{0,248}\end{array}$} \\
\hline & 1 & & & & & & \\
\hline & befor & 0,189 & 0,145 & & & & \\
\hline$A$ & after & 0,21 & 0,15 & 0,4 & 0,412 & 0,81 & 0,26 \\
\hline \multirow{2}{*}{ B } & befor & 0,44 & 0,09 & 0,35 & 0,6 & 1,3 & 0,2 \\
\hline & after & 0,5 & 0,1 & 0,39 & 0,66 & 1,41 & 0,2 \\
\hline \multirow{2}{*}{ C } & befor & 0,35 & 0,15 & 0,21 & 0,10 & 0,2 & 0,15 \\
\hline & after & 0,42 & 0,21 & 0,29 & 0,15 & 0,61 & 0,19 \\
\hline \multirow{2}{*}{$D$} & befor & 0,45 & 0,37 & 0,51 & 0,11 & 0,77 & 0,24 \\
\hline & after & 0,45 & 0,46 & 0,51 & 0,24 & 0,78 & 0,36 \\
\hline \multirow{2}{*}{$E$} & befor & 0,1 & 0,38 & 0,53 & 0,45 & 0,7 & 0,11 \\
\hline & after & 0,12 & 0,43 & 0,55 & 0,49 & 0,75 & 0,18 \\
\hline \multirow{2}{*}{$F$} & befor & 0,1 & 0,21 & 0,23 & 0,27 & 0,51 & 0,1 \\
\hline & after & 0,16 & 0,32 & 0,34 & 0,34 & 0,76 & 0,19 \\
\hline \multirow{2}{*}{ G } & befor & 0,5 & 0,5 & 0,49 & 0,31 & 1,00 & 0,29 \\
\hline & after & 0,5 & 0,5 & 0,5 & 0,44 & 1,12 & 0,31 \\
\hline \multirow{2}{*}{$\mathrm{H}$} & befor & 0,6 & 0,29 & 0,16 & 0,5 & 0,73 & 0,35 \\
\hline & after & 0,7 & 0,33 & 0,26 & 0,5 & 0,87 & 0,35 \\
\hline
\end{tabular}

Note: A - use of own capacities; B - useful electricity output; C - electricity tariffs; D - installed electric power; $\mathrm{E}$ - science-intensive technologies; $\mathrm{F}$ - the intensity of production; $\mathrm{G}$ - c lommodity products; $\mathrm{H}$ investment attractiveness.

Sources: developed by the authors

Conclusions. In the process of studying the scientific economic literature and periodicals on the problems of forming a checkpoint, a conceptual-categorical apparatus on the theory of CAIE was investigated, which revealed the terminological discrepancy of the concepts of «adaptive management» and "competitive advantages», generalizations and developed existing approaches to $A M$, which determined the importance of refinement the economic essence of the concept of «formation of a checkpoint on the principles of $A M »$, which is considered as the formation of a set of unique characteristics of the enterprise, determined by qualitative or quantitative their market position compared to competitors who provide financial and economic development of the company and a rapid and optimal adjustment to his sudden and unexpected changes in the external environment, including possible alternatives and consequences, and while maintaining the ability to interact with a modified environment and personality of its activities.

In order to increase the efficiency of the operation of the CA of industrial enterprises, the conceptual approach to the process of formation of a checkpoint on the principles of adaptive management based on a complex dynamic approach, which based on the principles of adaptability, systemicity, flexibility, efficiency, interconnectivity, adequacy and controllability is improved. Modelling adaptive reaction to unpredictable changes in the economic system.

Based on analysis of conditions of functioning of domestic industrial enterprises in the conditions of instability, a number of external and internal problems were identified, including unfavorable investment climate, the need to match the achievements of scientific and technological progress (with the wide introduction of advanced technologies) and lack of a management strategy in changing market conditions. 
Today, for industrial enterprises, the application of the principles of adaptive management of the CA is a decisive factor in achieving their sustainable competitiveness in the market of fuel energy, which is one of the strategic objectives of creating an effective system of management at enterprises that would provide them with stable CAIE. The practical application of the scientific-theoretical provisions and practical recommendations developed in the article enables industrial enterprises to reduce the costs of forming and evaluating competitive advantages, reducing the time spent on responding to unstable economic conditions, which is crucial for ensuring a firm competitive position in the industry. The scientificmethodological approaches and methods are tested within the framework of existing industrial enterprises are proposed

Author Contributions: conceptualization Z. S., F. O.; methodology, V. M., K. V.; validation, Z. S., V. M., formal analysis F. O.; investigation, K. V., F. O.; resources, V. M.; data curation, Z. S; writing original draft preparation, V. M., K. V.; writing - review and editing, F. O.; visualization, Z. S., V. M.; supervision, K. V., F. O.; project administration V. M., K. V., F. O.

\section{References}

Alana, L. Moore, Michael, A. (2009). «On Valuing Information in Adaptive-Management, Models». Conservation Biology. 24 (4): 984-993. doi:10.1111/j.1523-1739.2009.01443.x. PMID 20136870.

Australian Government Connected Water http://www.connected water.gov.au/framework/adaptive_management.html\%7C

Bartenev, S.A. (1997). History of economic exercises in questions and answers, M.: Lawyer, 356.

Berkes, F., Colding, J., Folke, C. (2000). Rediscovery of Traditional Ecological Knowledge as Adaptive Management. Ecological Applications, 10 (5): 1251-1262. doi:10.1890/1051-0761(2000)010[1251:ROTEKA]2.0.CO;2.

Chaffee, E. E. (1985). Three Models of Strategy. The Academy of Management Review, 10 (1): 89-98. doi:10.5465/amr.1985.4277354.

Derevitsky, D.P., Fradkov, A.L. (1980). The method of continuous models in the theory of discrete adaptive systems. Problems of cybernetics: tasks and methods of adaptive control, M: NA on cybernetics of the Academy of Sciences of the USSR, 75-98.

Dunphy, D., Griffths, A., Benn, S. (2007). Organizational Change for Corporate Sustainability, London: Routledge.

Elzinga, C.L., D. W. Salzer, J. W. Willoughby (1998). Measuring and Monitoring Plant Populations (PDF). Denver, CO: Bureau of Land Management. BLM Technical Reference 1730-1.

Fathutdinov, R.A. (2000). Competitiveness: Economics, Strategy, Management, M.: INFRA-M, 312.

Fomin, V.N. Fradkov, A.L., Yakubovich, V.A. (1981). Adaptive Control of Dynamic Objects, M.: Science, The Main Edition of Physics and Mathematical Literature, $448 \mathrm{p}$.

George, H. Stankey, Roger, N. Clark, Bernard, T. Bormann (2005). Adaptive Management of Natural Resources. Theory, Concepts, and Management Institutions (PDF). Washington: United States Department of Agriculture (USDA).

Global Communities (2016). M\&E for Collaboration, Learning and Adapting in PACE.

Gregory, R, Ohlson, D, Arvai, J (2006). «Deconstructing adaptive management: criteria for application to environmental management». Ecological Applications. 16 (6): 2411-2425. doi:10.1890/1051-0761(2006)016 [2411:DAMCFA]2.0.CO;2. PMID 17205914.

Hayek, F. A. (1999). Cognition, Competition and Freedom, St. Petersburg: Pneuma, 212.

Head, B., Alford, J. (2008). Wicked Problems: The Implications for Public Management, 12th Annual Conference International Research Society for Public Management, Panel on Public Management in Practice, Brisbane.

Karpenko, L., Serbov, M., Kwilinski, A., Makedon, V., \& Drobyazko, S. (2018). Methodological platform of the control mechanism with the energy saving technologies. Academy of Strategic Management Journal 17(5): 1939-6104-17-5-271: 1-7. Retrieved from https://www.abacademies.org/articles/Methodological-platform-of-the-control-mechanism-1939-6104-17-5-271.pdf

Kozlov, Yu. M. (1980). Methods of adaptation in robotics. Questions of cybernetics: tasks and methods of adaptive control, M.: NA on cybernetics of the Academy of Sciences of the USSR.

Kwilinski, A. (2018a). Mechanism for assessing the competitiveness of an industrial enterprise in the information economy. Research Papers in Economics and Finance, 3(1), 7-16. https://doi.org/10.18559/ref.2018.1.1

Kwilinski, A. (2018b). Mechanism of formation of industrial enterprise development strategy in the information economy, Virtual Economics, 1(1), 7-24. Retrieved from https://virtual-economics.eu/VE_1_1/Kwilinski_1_VE_1_1_2018_7-25.pdf

Kwilinski, A. (2018c). Mechanism of modernization of industrial sphere of industrial enterprise in accordance with requirements of the information economy, Marketing and Management of Innovations, 4, 116-128. http://doi.org/10.21272/mmi.2018.4-11

Lakhno, V., Malyukov, V., Bochulia, T., Hipters, Z., Kwilinski, A., \& Tomashevska, O. (2018). Model of managing of the procedure of mutual financial investing in information technologies and smart city systems. International Journal of Civil Engineering 
O. Farhshatova, S. Zaharov, M. Vereskun, V. Kolosok. Formation of Competitive Advantages of the Enterprise Based on Adaptive Management

and Technology, 9(8), 1802-1812. Retrieved from http://www.iaeme.com/MasterAdmin/UploadFolder/IJCIET_09_08_181/ IJCIET_09_08_181.pdf

Lepa, N.N. (2003). Managing the Competitive Benefits of an Enterprise. National Academy of Sciences of Ukraine. Institute of Industrial Economics. Donetsk: South East Ltd., 296.

Marshall, A. Principles of Political Economy: in 3 vol., M.: Progress, 1983-1984.

Porter, M. (1993). International Competition, M.: International relations, 896.

Porter, M. (1997). Competition Strategy, K.: Osnova, 392.

Pajak, K., Kamińska, B., \& Kvilinskyi, O. (2016). Modern trends of financial sector development under the virtual regionalization conditions. Financial and credit activity: problems of theory and practice, 2(21), 204-217. Retrieved from https://doi.org/10.18371/fcaptp.v2i21.91052

Pająk, K., Kvilinskyi, O.; Fasiecka, O., \& Miśkiewicz, R. (2017). Energy security in regional policy in Wielkopolska region of Poland. Economics and Environment, 2(61), 122-138. Retrieved from https://www.ekonomiaisrodowisko.pl/uploads/ eis\%2061/11_pajak.pdf

Payonk, K., Lyashenko, V., \& Kvilinskyi, O. (2015). Operation of a business entity in the context of globalization. Economic Herald of the Donbas, 4(42), 18-23.

Rondinell, D. A. (1993). Development Projects as Policy Experiments: an adaptive approach to development administration, vol. 2, Routledge, London and New York.

Rout, T.M., Hauser, C.E., Possingham, H.P. (2009). Optimal adaptive management for the translocation of a threatened species. Ecological Applications, 19 (2): 515-516. doi:10.1890/07-1989.1. PMID 19323207.

Shea, K., Possingham, H.P., Murdoch, W.W., Roush, R. (2002). Active Adaptive Management in Insect Pest and Weed Control. Intervention with a Plan for Learning. Ecological Applications, 12 (3): 927-936. doi:10.1890/10510761(2002)012[0927:AAMIIP]2.0.CO;2

Sragovich, V.G. (1981). Adaptive Management, M.: Science, Editorial Board of Physical and Mathematical Literature, 384

The Environmental Advisory Council (2002). Resilience and Sustainable Development. Building Adaptive Capacity in a World of Transformation. Stockholm.

Verine, L. (2008). Adaptive Project Management. PM World Today, 10 (5): 1-9.

Virine, Lev, Michael Trumper (2008). Project Decisions: The Art and Science. Vienna, VA: Management Concepts, ISBN 9781-56726-217-9

Vukobrativych, M. Stokich, D., Kirchanski, N. (1989). Non Adaptive and Adaptive Management of Manipulation Works, M.: Peace, 376.

Zlupko, S. (2005). History of Economic Theory, K.: Knowledge, 719.

О. Фархиатова, Ph.D., Інститут розвитку міжнародної співпраці (Польща);

C. Захаров, к.е.н., директор Метlнвест Пром Сервіс (Україна);

М. Верескун, д.е.н., Приазовський технічний університет (Україна);

В. Колосок, д.е.н., Приазовський технічний університет (Україна).

Концептуальний підхід до процесу формування конкурентних переваг підприємства на засадах адаптивного управління

У статті на основі аналізу та узагальнення низки наукових досліджень уточнено зміст понять «конкуренція» та «конкурентоспроможність підприємства». Досліджено актуальність проблем конкуренції і втрати конкурентоспроможності підприємствами в умовах поглиблення та розповсюдження наслідків економічних криз. Проаналізовано й узагальнено погляди на трактовку понять «адаптація» та «адаптивне управління промисловими підприємствами», обґрунтовано необхідність для сучасних підприємств застосовувати у процесах управління різні способи адаптації. Запропоновано концепцію формування конкурентних переваг підприємства на засадах адаптивного управління, в основу якого покладено комплексний динамічний підхід, досліджено взаємозв'язок принципів адаптивності, системності, гнучкості, ефрективності, взаємозв'язку адекватності й керованості із можливістю розвитку конкурентних переваг підприємства. Завданням концепції відповідає застосування адаптивних інтегрованих систем; системи планування ситуації в галузі і адаптивної системи регулювання; розробка очікуваних показників конкурентних переваг підприємства і відхилень від них; моделювання адаптивного реагування на зміни в реальній економічній системі. Дана кониепція дозволяє здійснювати процес управління конкурентними перевагами з максимальною ефективністю за рахунок чутливого реагування як на зовнішні непередбачувані зміни в галузі, так і внутрішні потенційні зміни на підприємстві. Проведено аналіз сучасних динамічних умов ффункціонування промислових підприємств України, виявлено низку зовнішніх та внутрішніх проблем, серед яких несприятливий інвестиційний клімат, необхідність відповідати досягненням науково-технічного прогресу (з широким впровадженням прогресивних 
O. Farhshatova, S. Zaharov, M. Vereskun, V. Kolosok. Formation of Competitive Advantages of the Enterprise Based on Adaptive Management

технологій) та відсутність стратегії господарювання за мінливих ринкових умов. Доведено, що для промислових підприємств сьогодні застосування принципів адаптивного управління є вирішальним фактором досягнення ними стійкої конкурентоспроможності на ринку паливної енергетики, що є однією із стратегічних задач створення ефективної системи управління на підприємствах, яка б забезпечувала їм стійкі конкурентні переваги

Ключові слова: адаптивне управління, конкурентні переваги, промислові підприємства, управління конкурентними перевагами

Manuscript received: 20.11.2018.

(C) The author(s) 2019. This article is published with open access at Sumy State University. 